\title{
Widespread temperature sensitivity and tRNA decay due to mutations in a yeast tRNA
}

\author{
MATTHEW J. PAYEA, ${ }^{1,5}$ MICHAEL F. SLOMA, ${ }^{1,5}$ YOSHIKO KON, ${ }^{1,5}$ DAVID L. YOUNG, ${ }^{2}$ MICHAEL P. GUY, \\ XIAOJU ZHANG, ${ }^{1}$ THAREENDRA DE ZOYSA, ${ }^{1}$ STANLEY FIELDS, ${ }^{2,3,4}$ DAVID H. MATHEWS, ${ }^{1}$ \\ and ERIC M. PHIZICKY ${ }^{1}$ \\ ${ }^{1}$ Department of Biochemistry and Biophysics and Center for RNA Biology, University of Rochester School of Medicine, Rochester, \\ New York 14642, USA \\ ${ }^{2}$ Department of Genome Sciences, University of Washington, Seattle, Washington 98195, USA \\ ${ }^{3}$ Department of Medicine, University of Washington, Seattle, Washington 98195, USA \\ ${ }^{4}$ Howard Hughes Medical Institute, University of Washington, Seattle, Washington 98195, USA
}

\begin{abstract}
Microorganisms have universally adapted their RNAs and proteins to survive at a broad range of temperatures and growth conditions. However, for RNAs, there is little quantitative understanding of the effects of mutations on function at high temperatures. To understand how variant tRNA function is affected by temperature change, we used the tRNA nonsense suppressor SUP4 ${ }_{\text {oc }}$ of the yeast Saccharomyces cerevisiae to perform a high-throughput quantitative screen of tRNA function at two different growth temperatures. This screen yielded comparative values for 9243 single and double variants. Surprisingly, despite the ability of $S$. cerevisiae to grow at temperatures as low as $15^{\circ} \mathrm{C}$ and as high as $39^{\circ} \mathrm{C}$, the vast majority of variants that could be scored lost half or more of their function when evaluated at $37^{\circ} \mathrm{C}$ relative to $28^{\circ} \mathrm{C}$. Moreover, temperature sensitivity of a tRNA variant was highly associated with its susceptibility to the rapid tRNA decay (RTD) pathway, implying that RTD is responsible for most of the loss of function of variants at higher temperature. Furthermore, RTD may also operate in a met22 strain, which was previously thought to fully inhibit RTD. Consistent with RTD acting to degrade destabilized tRNAs, the stability of a tRNA molecule can be used to predict temperature sensitivity with high confidence. These findings offer a new perspective on the stability of tRNA molecules and their quality control at high temperature.
\end{abstract}

Keywords: tRNA; tRNA decay; RNA temperature sensitivity; thermal stability; nonsense suppressor; SUP4

\section{INTRODUCTION}

tRNAs are highly evolved to efficiently and accurately incorporate amino acids during translation. Mutations in tRNA often result in reduced function, with serious consequences to cell viability and to human health; for example, over 230 mitochondrial tRNA mutations are associated with human disease, including mutations in every region of the molecule (Ruiz-Pesini et al. 2007). Two major properties of tRNA are conserved among all domains of life. First, virtually all tRNAs have a similar overall structure (Kim et al. 1974a; Westhof et al. 1985; Giegé et al. 2012) for efficient recognition by different parts of the translation machinery, for flexibility in passage through the ribosome (Valle et al. 2003; Schmeing et al. 2009; Zhou et al. 2013), and for stability through multiple

\footnotetext{
${ }^{5}$ These authors contributed equally to this work.

${ }^{6}$ Present address: Department of Chemistry, Northern Kentucky University, Highland Heights, KY 41076, USA

Corresponding authors: eric_phizicky@urmc.rochester.edu, david_mathews@urmc.rochester.edu

Article is online at http://www.rnajournal.org/cgi/doi/10.1261/rna. 064642.117 .
}

rounds of translation (Alexandrov et al. 2006; Whipple et al. 2011; Dewe et al. 2012). Second, all tRNAs have unique sequence elements for efficient and highly selective decoding of mRNA and for charging by their cognate tRNA synthetase (Giege et al. 1998; Cochella and Green 2005; Ledoux et al. 2009; Ling et al. 2009; Shepotinovskaya and Uhlenbeck 2013). tRNAs are also subject to ubiquitous post-transcriptional modifications, and these aid in all aspects of tRNA function (Pütz et al. 1994; Helm et al. 1999; Johansson et al. 2008; Demeshkina et al. 2010; Maehigashi et al. 2014; Grosjean and Westhof 2016; Rozov et al. 2016).

To ensure that the structural requirements for tRNA are met, $\mathrm{tRNAs}$ are subject to several quality control pathways. In the yeast Saccharomyces cerevisiae, these pathways recycle certain hypomodified tRNAs back to the nucleus (Shaheen

\footnotetext{
(C) 2018 Payea et al. This article is distributed exclusively by the RNA Society for the first 12 months after the full-issue publication date (see http://rnajournal.cshlp.org/site/misc/terms.xhtml). After 12 months, it is available under a Creative Commons License (Attribution-NonCommercial 4.0 International), as described at http://creativecommons.org/licenses/by-nc/ $4.0 /$
} 
and Hopper 2005; Takano et al. 2005) for modifications during biogenesis (Ohira and Suzuki 2011) and for possible repair (Kramer and Hopper 2013); degrade wild-type (WT) and certain hypomodified pre-tRNAs by the nuclear surveillance pathway (Kadaba et al. 2004, 2006; Gudipati et al. 2012); and degrade mature tRNAs through the rapid tRNA decay (RTD) pathway if they lack specific modifications or have destabilizing mutations (Alexandrov et al. 2006; Chernyakov et al. 2008; Whipple et al. 2011; Guy et al. 2014). In humans there is also evidence that RTD occurs at high temperature (Watanabe et al. 2013).

Although it is well known that RNA stability has a direct effect on RNA function at different temperatures, there is little quantitative information on the effects of mutations on RNA function at different temperatures. This problem has been addressed to some extent in quantifying regulation of gene expression by RNA thermometers in response to mutations that affect stability of regulatory helices (Chowdhury et al. 2003; Kortmann and Narberhaus 2012; Cimdins et al. 2014). More typically, RNA function at different temperatures is only analyzed qualitatively, as in the analysis of destabilizing mutations that counteract the cold sensitivity of a stabilizing stem mutation of U6 snRNA (Fortner et al. 1994), and the analysis of reduced growth at high temperatures due to several destabilizing tRNA variants (Whipple et al. 2011). Although high-throughput studies have been used to quantify the effects of sequence variation on the function of a catalytic RNA (Pitt and Ferre-D'Amare 2010) and of a tRNA (Guy et al. 2014; Li et al. 2016) under a specific set of conditions, there have been no such studies on how sequence variation affects RNA function at different temperatures.

Analysis of the tolerance of RNAs to temperature is inherently important for two reasons. First, all organisms grow well over a broad range of temperatures and therefore require cellular components such as tRNAs to function relatively uniformly throughout these conditions. Yeast, for example, grow relatively well from $15^{\circ} \mathrm{C}$ to $39^{\circ} \mathrm{C}$. Second, there is likely strong evolutionary pressure on the thermal stability of tRNAs and other functional RNAs, given the positive correlation between $\mathrm{G}-\mathrm{C}$ content (Galtier and Lobry 1997) or predicted RNA structural stability (Lu et al. 2006) and the optimal growth temperature of an organism.

We report here the first comprehensive analysis of the effects of sequence variation on the function of an RNA, the tRNA suppressor $S U P 4_{o c}$. We previously developed a highthroughput approach to comprehensively quantify the effects of mutations on the function of $S U P 4_{o c}$ and to define the spectrum of mutations that trigger tRNA decay by the RTD pathway at a specific temperature (Guy et al. 2014). In this work, we extend this approach to define the effects of sequence variation on $S U P 4_{o c}$ function at a higher temperature, and to evaluate the connections between temperature sensitivity and susceptibility to the RTD pathway. We find evidence that temperature sensitivity of tRNA variants occurs frequently and is associated with thermodynamic parameters and RTD.

\section{RESULTS}

\section{High-throughput quantification of tRNA temperature sensitivity}

We examined the effects of high temperature on the function of the yeast nonsense suppressor tRNA SUP4 $4_{o c}$, using our previously described approach, which measures the relative in vivo function of each tRNA in a library of variants (Guy et al. 2014). SUP4 ${ }_{o c}$ tRNA function was evaluated using a version of the RNA-ID reporter (Dean and Grayhack 2012) expressing $\mathrm{GFP}_{\text {oc }}$ (suppressible by $S U P 4_{o c}$ ) and RFP, each transcribed in opposite directions under the control of the bidirectional $\mathrm{P}_{G A L 1,10}$ promoter (Supplemental Fig. S1A). Thus, cells bearing a more functional $S U P 4_{o c}$ tRNA variant will have a higher ratio of GFP ${ }_{\text {oc }}$ to RFP (Guy et al. 2014).

We grew the yeast library of $S U P 4_{o c}$ variants to log phase at $37^{\circ} \mathrm{C}$ and sorted cells by their GFP/RFP score into four bins using fluorescence activated cell sorting (FACS) (Supplemental Fig. S1B). We extracted DNA from each bin, deep sequenced the SUP4 $4_{o c}$ gene to determine the distribution of each variant among the bins, and converted the distribution to a $\mathrm{GFP}^{\mathrm{SEQ}}$ score that reflects the variant's function relative to WT SUP $4_{o c}$ under the same conditions (Supplemental Table S1; see Materials and Methods). Variants were categorized as nonfunctional $\left(\mathrm{GFP}^{\mathrm{SEQ}}<0.026\right.$, the smallest value that could be distinguished from zero), marginally functional $(0.026 \leq$ $\left.\mathrm{GFP}^{\mathrm{SEQ}}<0.18\right)$, substantially functional $\left(0.18 \leq \mathrm{GFP}^{\mathrm{SEQ}}<\right.$ $0.9)$, and highly functional (GFP ${ }^{\mathrm{SEQ}} \geq 0.9$ ) (Guy et al. 2014). $\mathrm{GFP}_{37}^{\mathrm{SEQ}}$ values for individual variants were strongly correlated among four biological replicates, with $R^{2}$ values $\geq 0.9$ for every pairwise comparison of data sets (Supplemental Table S1; Supplemental Fig. S2A), which is comparable to the reproducibility between replicates in our previous data sets at $28^{\circ} \mathrm{C}$ (Guy et al. 2014). For further analysis, we chose the biological replicate that contained the largest number of unique variants, replicate 1 (labeled 37deg in Supplemental Table S1). As an additional quality-control measure, we reconstructed 12 variants from the $37^{\circ} \mathrm{C}$ data set and measured their GFP/RFP ratio, normalized to WT $S U P 4_{o c}$, by flow cytometry $\left(\mathrm{GFP}^{\mathrm{FLOW}}\right)$ at $37^{\circ} \mathrm{C}$. As with the previous $28^{\circ} \mathrm{C}$ data set, $\mathrm{GFP}^{\mathrm{FLOW}}{ }_{37}$ and $\mathrm{GFP}^{\mathrm{SEQ}}{ }_{37}$ were strongly correlated, with an $R^{2}$ value of 0.86 (Supplemental Fig. S2B).

After filtering for data quality (see Materials and Methods), the $37^{\circ} \mathrm{C}$ data set contained 25,191 variants, including 212/ 213 possible single variants, 9321 double variants, and 8441 triple variants (Supplemental Table S2). Of these, 24,282 variants were also present in our $28^{\circ} \mathrm{C}$ data set (Guy et al. 2014). The high degree of overlap between the $28^{\circ} \mathrm{C}$ and $37^{\circ} \mathrm{C}$ data sets reflects saturation in sampling of the library.

\section{The majority of SUP4 ${ }_{o c}$ variants are temperature sensitive}

Almost all of the variants decreased in function in MET22 cells, defined here as $\mathrm{WT}$, at $37^{\circ} \mathrm{C}$ relative to $28^{\circ} \mathrm{C}$ 
(Supplemental Table S2; Supplemental Fig. S3; Fig. 1A). Indeed, only seven of the 47 highly functional single variants at $28^{\circ} \mathrm{C}$ remained highly functional at $37^{\circ} \mathrm{C}$, and a similar loss of function was observed among the substantially functional single variants and among all double variants. To quantify temperature sensitivity, we defined the temperature sensitive (TS) ratio as $\mathrm{GFP}^{\mathrm{SEQ}}{ }_{28} / \mathrm{GFP}^{\mathrm{SEQ}}{ }_{37}$ and considered a variant $\mathrm{TS}$ if this ratio was $\geq 2$. A variant could be assigned a TS ratio only if its $\mathrm{GFP}^{\mathrm{SEQ}}{ }_{28}$ score was $\geq 0.052$, twice the smallest $\mathrm{GFP}^{\mathrm{SEQ}}$ value (0.026) distinguishable from background (Guy et al. 2014). Using this scoring metric, we assigned TS ratios to 76 single variants (Fig. 1B) and 821 double variants (Supplemental Table S2). Temperature sensitivity was the rule rather than the exception, with 57\% (43/76) of the single variants and $75 \%(613 / 821)$ of the double variants classified as TS. Temperature sensitivity occurred in tRNA variants with a wide range of $\mathrm{GFP}^{\mathrm{SEQ}}{ }_{28}$ scores including $59.1 \%$ (169/286) of the highly functional single and double variants, $74.2 \%(216 / 291)$ of the substantially functional variants, and $84.6 \%(271 / 320)$ of the marginally functional variants. The lower prevalence of temperature sensitivity among the highly

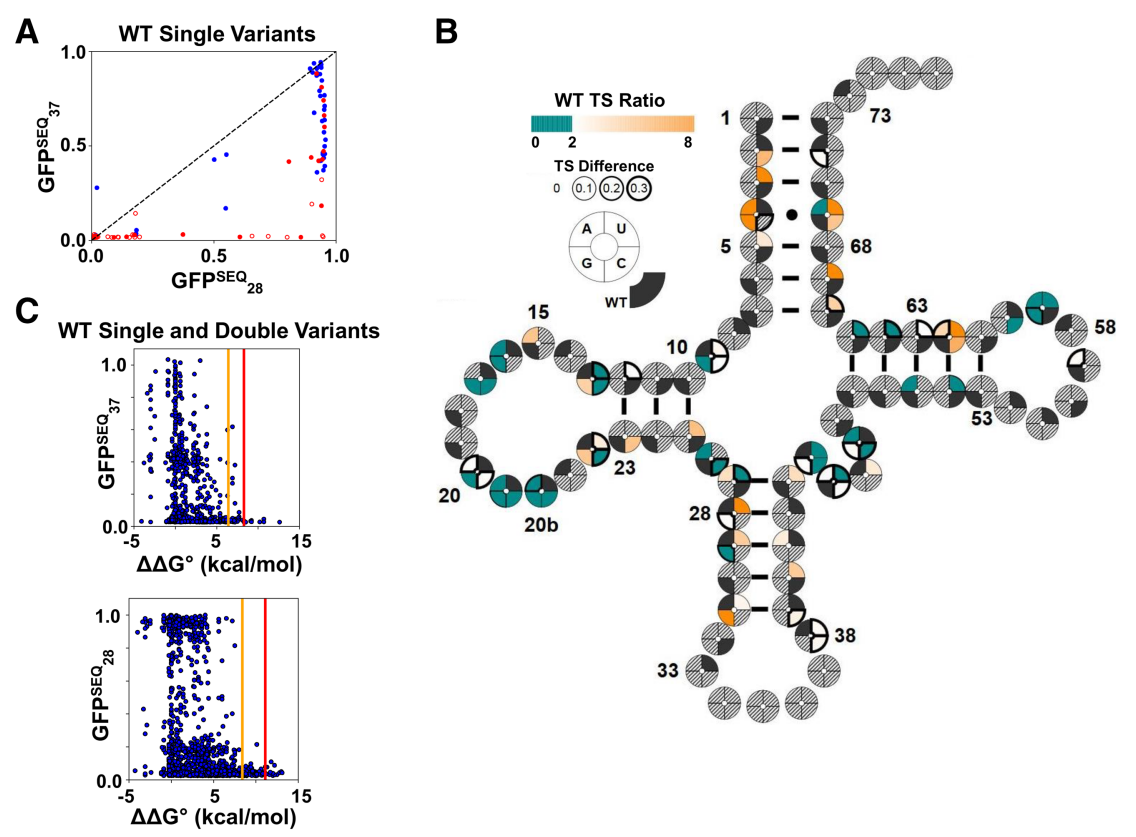

FIGURE 1. The majority of $S U P 4_{o c}$ variants are temperature sensitive in WT cells at $37^{\circ} \mathrm{C}$. $(A)$ Most $S U P 4_{o c}$ single variants have reduced $\mathrm{GFP}^{\mathrm{SEQ}}$ values at $37^{\circ} \mathrm{C}$ relative to $28^{\circ} \mathrm{C}$. $\mathrm{GFP}^{\mathrm{SEQ}}{ }_{37}$ scores in WT cells were compared to GFP ${ }^{\mathrm{SEQ}}{ }_{28}$ scores previously obtained in WT cells (Guy et al. 2014). Variants below the dashed line decreased in function at $37^{\circ} \mathrm{C}$, while variants above increased in function. Variants in loops, blue; variants in stems, solid red (base pair preserved) or open red (base pair broken). (B) Temperature-sensitive $S U P 4_{o c}$ single variants are widespread. Cloverleaf heatmap depicting TS scores for SUP4 ${ }_{o c}$ single variants in WT cells, as measured by $\mathrm{GFP}^{\mathrm{SEQ}}{ }_{28} /$ $\mathrm{GFP}^{\mathrm{SEQ}}$ 37. TS variants, shades from white to orange; non-TS variants, teal; variants not scored, stippled. Nucleotides $34-37$ and the post-transcriptionally added CCA were not subject to variation. TS difference $\left(\mathrm{GFP}^{\mathrm{SEQ}}{ }_{28}-\mathrm{GFP}^{\mathrm{SEQ}}{ }_{37}\right)$ is indicated by the thickness of each variant's wedge. (C) The calculated $\Delta \Delta G^{\circ}$ thresholds for variant function are higher at $28^{\circ} \mathrm{C}$ than at $37^{\circ} \mathrm{C}$. For each single and double variant, the GFP ${ }^{\mathrm{SEQ}}$ is plotted against its calculated $\Delta \Delta G^{\circ}$ at $37^{\circ} \mathrm{C}$ (top panel) and $28^{\circ} \mathrm{C}$ (lower panel). Note that $95 \%$ of functional variants have $\Delta \Delta G^{\circ}$ less than that of the gold line; red line, $99 \%$. functional variants could be due in part to the saturation of $\mathrm{GFP}_{28}^{\mathrm{SEQ}}$ at $\mathrm{GFP}^{\mathrm{FLOW}}$ scores $>0.45$, which was previously observed (Guy et al. 2014), and would reduce our ability to solve modest temperature sensitivity among these variants. TS variants were most often located in stems (Fig. 1B). The 42) of the scoreable single variants with loop mutations variants represents a significant enrichment in stem mutations associated with a TS phenotype ( $\chi^{2}$ test, $\left.P<0.05\right)$, supporting a role for structure in the TS phenotype.

Double variants that were TS likewise frequently bore mutations in or adjacent to stems. Among the scoreable double variants, $76.7 \%$ $(551 / 718)$ of the variants with at least one mutation in or adjacent to a stem were TS, while only $60.2 \%(62 / 103)$ of the variants with mutations only in loops were TS $(P<0.005)$.

Interestingly, variants at locations of dihydrouridine modification were particularly likely to be non-TS. This category includes all variants at residues $\mathrm{U}_{16}$, $\mathrm{U}_{17}, \mathrm{U}_{20 \mathrm{a}}, \mathrm{U}_{20 \mathrm{~b}}$, two variants at residue $\mathrm{U}_{47}$, and one variant at residue $\mathrm{U}_{20}$. Together, these variants accounted for the majority (15/26) of the non-TS single variants with loop mutations.

Given the strong connection between temperature sensitivity and stem mutations, which are known to affect structural stability, we tested if temperature sensitivity was a result of a more stringent threshold for correct folding imposed by high temperature. For this analysis, we used two approaches. First, we calculated the $\Delta \Delta G^{\circ}$ for the secondary structure of each variant, defined as its predicted change in stability from the native $S U P 4_{\text {oc }}$ structure for each variant, as estimated by the folding free energy change nearest neighbor model of RNA stability (Turner and Mathews 2010). We observed that tRNA function was highly dependent on $\Delta \Delta G^{\circ}$, particularly at $37^{\circ} \mathrm{C}$; at $37^{\circ} \mathrm{C}, 95 \%$ of single and double variants 
that were at least marginally functional had $\Delta \Delta G^{\circ}<6 \mathrm{kcal} /$ $\mathrm{mol}$, compared to a threshold of $<8 \mathrm{kcal} / \mathrm{mol}$ at $28^{\circ} \mathrm{C}$ (Fig. $1 \mathrm{C}$, gold lines). There was a similar trend based on a $99 \%$ cutoff (Fig. 1C, red lines). Second, we calculated a normalized ensemble defect for each variant, which uses a scale of zero to one to reflect the propensity for an RNA secondary structure to misfold, where one represents completely misfolded RNA (Zadeh et al. 2011), and observed the same trend as $\Delta \Delta G^{\circ}$. At $37^{\circ} \mathrm{C}, 95 \%$ of single and double variants that were at least marginally functional had ensemble defects less than 0.16 (Supplemental Fig. S4, gold lines), compared to an ensemble defect cutoff of 0.21 for $S U P 4_{o c}$ variants at $28^{\circ} \mathrm{C}$ (Guy et al. 2014), and a similar trend held for a $99 \%$ cutoff (Supplemental Fig. S4, red lines).

\section{$A_{46} G$ variants are often cold sensitive}

Although the overwhelming majority of $S U P 4_{o c}$ single and double variants were temperature sensitive, 11 variants had $\mathrm{GFP}^{\mathrm{SEQ}}$ scores that increased more than twofold at $37^{\circ} \mathrm{C}$, indicative of cold-sensitivity ( $\mathrm{CS}$ ratio $>2$ ) (Supplemental Table S2). Many of these $C S$ variants included the $\mathrm{A}_{46} \mathrm{G}$ mutation. The $\mathrm{A}_{46} \mathrm{G}$ single variant was much more active at $37^{\circ} \mathrm{C}$, with a $\mathrm{GFP}^{\mathrm{SEQ}}{ }_{37}$ score of 0.279 compared to 0.026 at $28^{\circ} \mathrm{C}$ ( $\mathrm{CS}$ ratio of 10.71), and seven other double mutant variants with an $\mathrm{A}_{46} \mathrm{G}$ mutation also had high-CS ratios, ranging from 13.27 to 2.13 (Supplemental Table S2). Subsequent examination by flow cytometry showed that the $\mathrm{A}_{46} \mathrm{G}$ single variant was active at $37^{\circ} \mathrm{C}(\mathrm{GFP} / \mathrm{RFP}, 0.324)$, but had near background levels of activity at $28^{\circ} \mathrm{C}(0.020)$ and $23^{\circ} \mathrm{C}(0.013)$ (Fig. $\left.2 \mathrm{~A}\right)$.

A

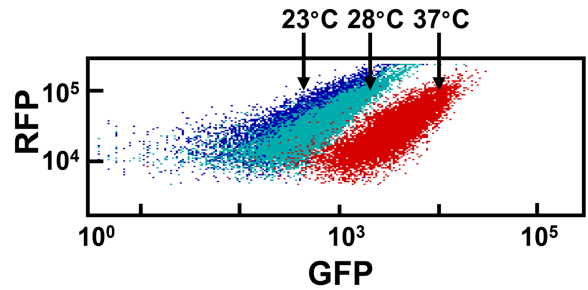

B

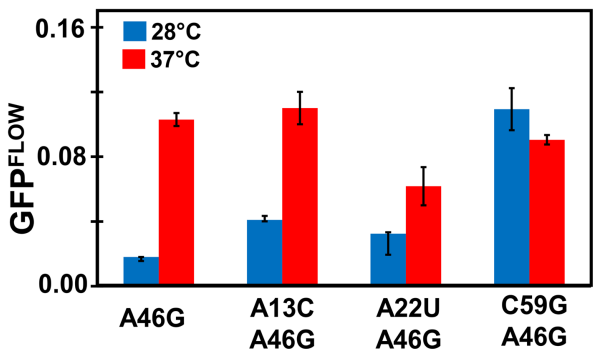

FIGURE 2. The $\mathrm{A}_{46} \mathrm{G}$ mutation confers cold sensitivity. (A) The $S U P 4_{o c}$ $\mathrm{A}_{46} \mathrm{G}$ single variant is cold sensitive. The $\mathrm{A}_{46} \mathrm{G}$ variant was subjected to flow cytometry at $23^{\circ} \mathrm{C}$, blue; $28^{\circ} \mathrm{C}$, cyan; and $37^{\circ} \mathrm{C}$, red, and scatterplots were generated from GFP and RFP values for 10,000 cells. (B) Double variants containing the $\mathrm{A}_{46} \mathrm{G}$ mutation are cold sensitive. Variants as indicated were subjected to flow cytometry in biological triplicate, and the median $\mathrm{GFP}^{\mathrm{FLOW}}$ was determined at $28^{\circ} \mathrm{C}$, blue; and $37^{\circ} \mathrm{C}$, red.
The CS phenotype of $\mathrm{A}_{46} \mathrm{G}$ also extends to one of three tested double variants with this mutation, using $\mathrm{GFP}^{\mathrm{FLOW}} ; \mathrm{A}_{46} \mathrm{G}$ and $\mathrm{A}_{13} \mathrm{C} \mathrm{A}_{46} \mathrm{G}$ had $\mathrm{CS}$ ratios of 5.72 and 2.68, respectively, while $\mathrm{A}_{22} \mathrm{U} \mathrm{A}_{46} \mathrm{G}$ and $\mathrm{C}_{59} \mathrm{G} \mathrm{A}_{46} \mathrm{G}$ had $\mathrm{CS}$ ratios of 1.91 and 0.83 , respectively (Fig. $2 \mathrm{~B}$ ).

\section{Temperature sensitivity is linked to the rapid tRNA decay pathway}

We speculated that the RTD pathway might be responsible for the high prevalence of temperature sensitivity that we observed in WT $\left(M E T 22^{+}\right)$cells, since RTD degrades tRNAs that are destabilized due to lack of certain modifications or to the presence of mutations that adversely affect structure, and is generally more efficient at higher temperatures (Chernyakov et al. 2008; Whipple et al. 2011; Guy et al. 2014).

To define RTD substrates at high temperature, we tested the library of $S U P 4_{o c}$ variants at $37^{\circ} \mathrm{C}$ in a met $22 \Delta$ mutant, which lacks a functional RTD pathway (Chernyakov et al. 2008; Whipple et al. 2011; Dewe et al. 2012), as we previously did at $28^{\circ} \mathrm{C}$ (Guy et al. 2014). This data set allowed us not only to evaluate the relationship between temperature sensitivity and RTD in WT cells, but also to evaluate temperature sensitivity in the absence of RTD in the met22 $\Delta$ mutant (Supplemental Fig. S5). Replicates of the GFP ${ }^{\mathrm{SEQ}}$ data set derived from the library of $S U P 4_{o c}$ variants in a met22 $\Delta$ strain had a strong correlation $\left(R^{2}>0.9\right)$ at $37^{\circ} \mathrm{C}$ (Supplemental Fig. S2A), and we used replicate \#2 for the comparisons below. We scored variants for RTD at $37^{\circ} \mathrm{C}$ based on the $\mathrm{RTD}_{37}$ ratio $\left(\mathrm{GFP}^{\mathrm{SEQ}}{ }_{37} m e t 22 \Delta / \mathrm{GFP}^{\mathrm{SEQ}}{ }_{37} \mathrm{MET}_{2} 2^{+}\right)$. We defined variants with an $\mathrm{RTD}_{37}$ ratio $\geq 2$ as RTD substrates, and therefore only scored variants with a $\mathrm{GFP}^{\mathrm{SEQ}}{ }_{37}$ met $22 \Delta$ $\geq 0.052$, twice the background (Guy et al. 2014). This filter resulted in an $\mathrm{RTD}_{37}$ score for 72 single variants and 480 double variants.

We found that 24/72 single variants were RTD substrates at $37^{\circ} \mathrm{C}$ (Fig. 3A), 13 of which were previously identified as RTD substrates at $28^{\circ} \mathrm{C}$. Of the 11 single variant RTD substrates unique to $37^{\circ} \mathrm{C}$, six contained mutations in the acceptor stem, four of which change $\mathrm{G}-\mathrm{C}$ pairs to less stable $\mathrm{G}-\mathrm{U}$ wobble pairs $\left(\mathrm{C}_{3} \mathrm{U}, \mathrm{C}_{66} \mathrm{U}, \mathrm{C}_{67} \mathrm{U}\right.$, and $\left.\mathrm{C}_{69} \mathrm{U}\right)$, and two of which form mismatches in the $\mathrm{U}_{4}-\mathrm{G}_{69}$ wobble pair $\left(\mathrm{U}_{4} \mathrm{~A}\right.$ and $\left.\mathrm{U}_{4} \mathrm{G}\right)$. Of the remaining five variants that were uniquely $\mathrm{RTD}_{37}$ substrates, two had mismatch mutations in other stems $\left(\mathrm{G}_{62} \mathrm{U}\right.$ and $\left.\mathrm{A}_{28} \mathrm{U}\right)$, two affected the nucleotides immediately adjacent to the $D$-stem $\left(A_{13} G, A_{22} G\right)$, and one was in the variable arm $\left(\mathrm{A}_{46} \mathrm{U}\right)$.

To understand the relationship between temperature sensitivity in WT cells and RTD, we examined the overlap between temperature sensitivity and RTD at either $28^{\circ} \mathrm{C}$ or $37^{\circ} \mathrm{C}$, for single and double variants that were present in each data set. Strikingly, $91.0 \%(161 / 177)$ of the variants that were strongly TS in WT cells (TS ratio $\geq 4$ ) were RTD substrates at either $28^{\circ}$ $\mathrm{C}$ or $37^{\circ} \mathrm{C}$ (Fig. 3B), whereas only $40.3 \%$ (29/72) of the variants that were strongly not TS in WT cells (TS ratio $<1.25$ ) 


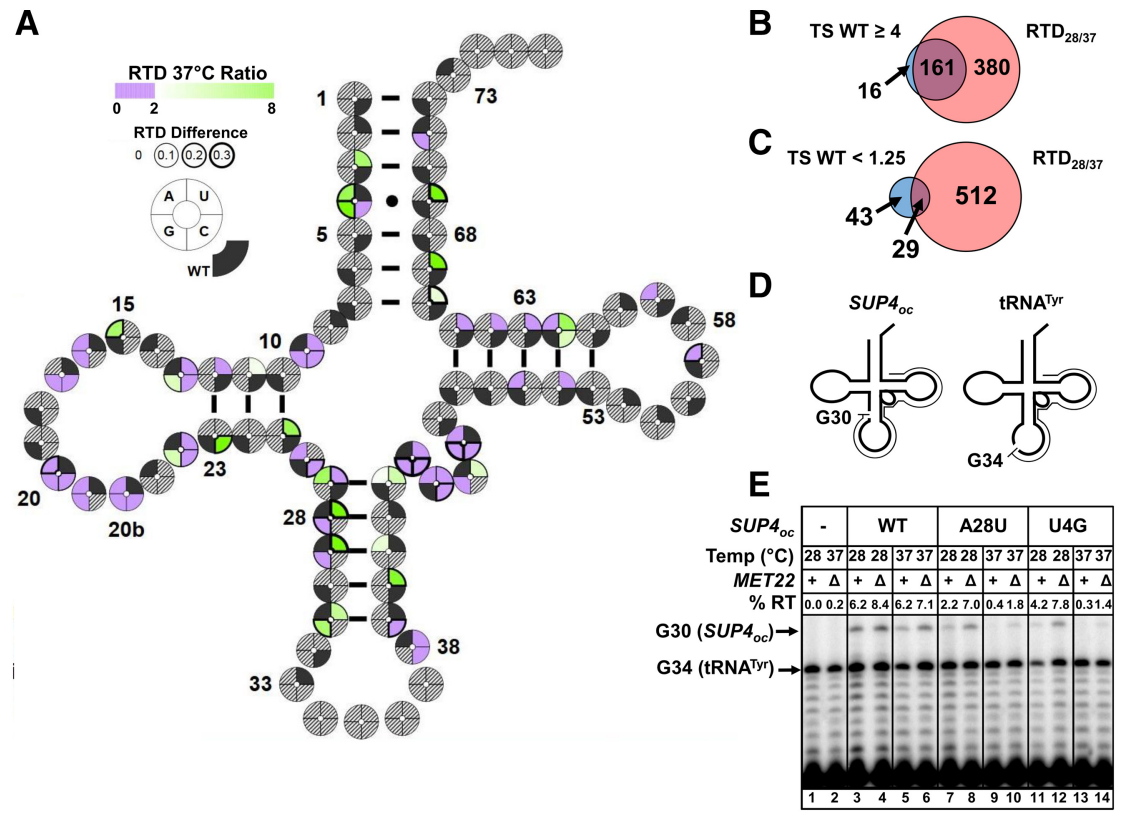

FIGURE 3. RTD is widespread at $37^{\circ} \mathrm{C}$ and associated with temperature sensitivity. (A) RTD substrates at $37^{\circ} \mathrm{C}$ include variants throughout the tRNA. Cloverleaf heatmap depicting RTD scores for $\mathrm{SUP}_{o c}$ single variants, as measured by $\mathrm{GFP}^{\mathrm{SEQ}}{ }_{37}$ met $22 \Delta / \mathrm{GFP}^{\mathrm{SEQ}}{ }_{37}$ WT. RTD Substrates (RTD score $\geq 2$ ), shades of white to green; non-RTD substrates, purple. RTD difference $\left(\mathrm{GFP}^{\mathrm{SEQ}}{ }_{37}\right.$ met $\left.22 \Delta-\mathrm{GFP}^{\mathrm{SEQ}}{ }_{37} \mathrm{WT}\right)$ is indicated by the thickness of the wedge for each variant. $(B)$ Strongly TS variants are overwhelmingly substrates for RTD at $28^{\circ} \mathrm{C}$ or $37^{\circ} \mathrm{C}$. Venn diagram showing the relationship between variants that are scored as strongly TS in WT (TS ratio $\geq 4$ ) (blue) and variants that are scored as RTD substrates at $37^{\circ} \mathrm{C}$ or $28^{\circ} \mathrm{C}$ (red). Overlap region (purple). (C) Strongly non-TS variants are often not substrates for RTD at $28^{\circ} \mathrm{C}$ or $37^{\circ} \mathrm{C}$. Venn diagram showing the relationship between variants that are strongly not TS in WT (TS ratio $\leq 1.25$ ) (blue) and variants that are RTD at $37^{\circ} \mathrm{C}$ (red). Overlap region (purple). (D) Schematic of poison primer extension in the presence of ddCTP to separate endogenous RNAA $^{\mathrm{Tyr}}$ from integrated $S U P 4_{o c}$ variants. (E) SUP4 ${ }_{o c}$ variants identified as RTD substrates at $37^{\circ} \mathrm{C}$ have increased tRNA levels in a met $22 \Delta$ strain. Poison primer extension was used to quantify tRNA levels from the bulk RNA of cells grown in steady state at $28^{\circ} \mathrm{C}$ or $37^{\circ} \mathrm{C} . S U P 4_{o c}$ tRNA levels were quantified relative to WT tRNA ${ }^{\text {Tyr }}$ by determining percent read-through (\% RT).

were RTD substrates at either temperature (Fig. 3C). This high degree of association between temperature sensitivity and RTD was even more pronounced for higher thresholds of TS ratios. For example, $96.5 \%(111 / 115)$ of the variants that were very strongly TS in WT cells (TS ratio >6) were RTD substrates at either $28^{\circ} \mathrm{C}$ or $37^{\circ} \mathrm{C}$. Conversely, decreasing the threshold reduced the percentage of TS WT variants that were RTD substrates, to $84 \%$ for TS ratio $\geq 3$ and to $55.5 \%$ for TS ratio $\geq 2$. The strong association between temperature sensitivity in WT cells and RTD susceptibility suggests that the majority of temperature sensitivity in WT cells is due to increased susceptibility to the RTD pathway.

We examined the association between RTD and temperature sensitivity for two variants (A28U and U4G) that were TS in WT cells and subject to RTD at $37^{\circ} \mathrm{C}$, by measuring their tRNA levels using a poison primer extension assay (Fig. 3D). This analysis showed that each variant had substantially reduced tRNA levels in a WT strain at $37^{\circ} \mathrm{C}$ compared to $28^{\circ}$ C (Fig. 3E, cf. lanes 7 and 9, and lanes 11 and 13), but had increased tRNA levels in a met $22 \Delta$ strain at $37^{\circ} \mathrm{C}$ compared to a
WT strain at $37^{\circ} \mathrm{C}$ (cf. lanes 9 and 10 , and lanes 13 and 14); in contrast SUP4 ${ }_{o c}$ itself was largely unchanged in all of these conditions (lanes 3-6).

\section{SUP4 $4_{\text {oc }}$ variants are frequently temperature sensitive in a met22 2 mutant}

Although much of the temperature sensitivity of WT cells was connected to RTD at $28^{\circ} \mathrm{C}$ or $37^{\circ} \mathrm{C}$, we also observed pervasive temperature sensitivity of $S U P 4_{o c}$ variants in met $22 \Delta$ cells (Supplemental Table S2), in which RTD is inhibited. Of the 96 single variants that could be scored for temperature sensitivity in met $22 \Delta$ cells, 53 were TS (Fig. 4A; Supplemental Fig. S6A), while $72.7 \%$ $(885 / 1217)$ of the double variants were TS in a met $22 \Delta$ strain (Supplemental Fig. S6B). As we observed for TS variants in WT cells, TS variants in met22 $\Delta$ cells overwhelmingly had at least one mutation in or adjacent to stems, accounting for $98 \%(52 / 53)$ of the TS single variants and $93 \%(823 / 885)$ of the TS double variants (Supplemental Table S2).

There was also an unexpectedly strong association between variants that were TS in met $22 \Delta$ strains and those that were TS in WT strains. Of the 52 TS single variants in met $22 \Delta$ cells that had $\mathrm{GFP}^{\mathrm{SEQ}}$ scores in all data sets, 26 were also TS in WT cells, and all but three of the remaining variants were not scoreable for temperature sensitivity in WT cells because their GFP ${ }_{28}^{\mathrm{SEQ}}$ scores were less than the required cutoff of 0.052 . This trend extended both to double variants and to strongly TS single and double variants. For example, of the 525 double variants that were TS in met $22 \Delta$ cells and had GFP ${ }^{\mathrm{SEQ}}$ scores in all data sets, 252 were TS in WT cells and 229 of the remaining 273 were not scoreable for temperature sensitivity (Supplemental Table S2).

\section{Temperature sensitivity is associated with tRNA decay in met22 24 cells}

The strong associations between the set of WT TS variants and the sets of met $22 \Delta$ TS variants and of RTD variants presented the possibility that the set of met $22 \Delta$ TS variants was also associated with the set of RTD variants. Indeed, among single and double variants that had $\mathrm{GFP}^{\mathrm{SEQ}}$ scores in all data sets, $81.1 \%(468 / 577)$ of met $22 \Delta$ TS variants were also subject to $\mathrm{RTD}$ at $28^{\circ} \mathrm{C}$ or $37^{\circ} \mathrm{C}$ (Fig. $4 \mathrm{~B}$ ), and this ratio 
A

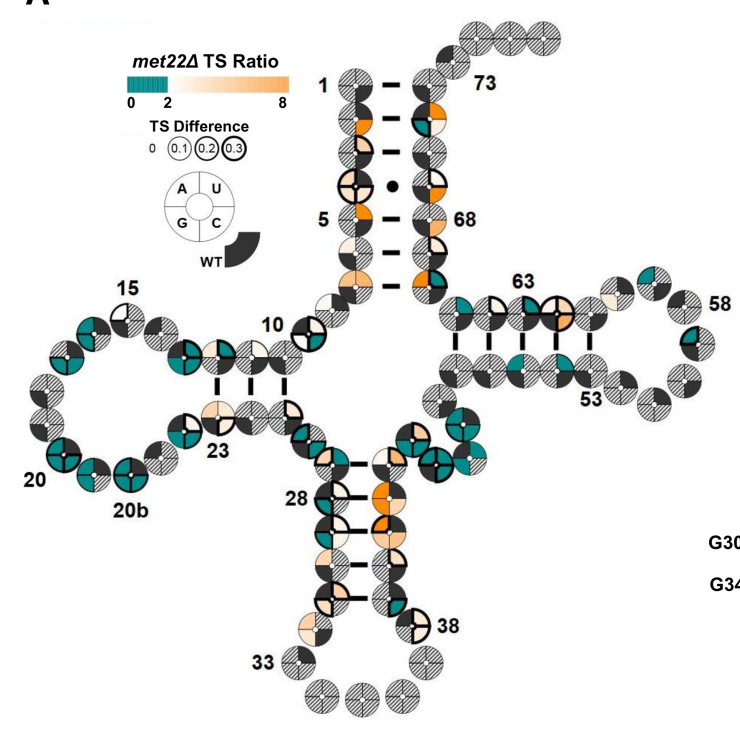

B

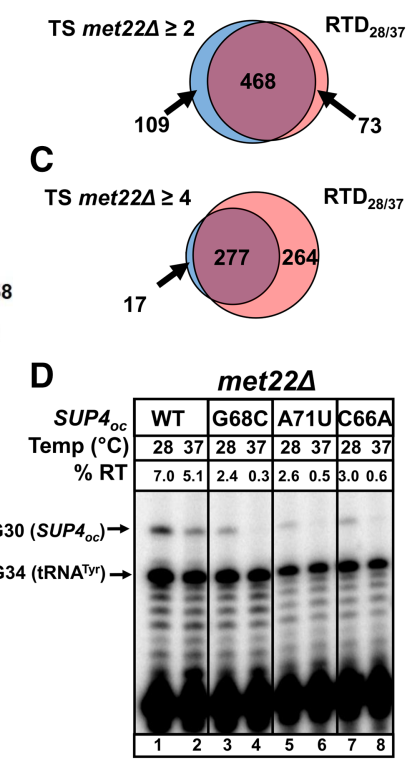

FIGURE 4. Temperature sensitivity is common in met22 $\Delta$ cells, and is associated with RTD. $(A)$ The majority of $S U P 4_{o c}$ variants are temperature sensitive in a met $22 \Delta$ strain. Cloverleaf heatmap depicting TS scores for $S U P 4_{o c}$ single variants in met $22 \Delta$ as measured by $\mathrm{GFP}_{28}^{\mathrm{SEQ}} / \mathrm{GFP}_{37}^{\mathrm{SEQ}}$. Shading and symbols as in Figure 1B. $(B, C) S U P 4_{o c}$ variants that are TS in met22 $\Delta$ are almost all substrates for RTD at $28^{\circ} \mathrm{C}$ or $37^{\circ} \mathrm{C}$. Venn diagram showing the relationship between variants that are RTD at $28^{\circ} \mathrm{C} / 37^{\circ} \mathrm{C}$ (blue) and variants that are TS in met $22 \Delta$ (red), with overlap, purple, for a TS ratio $>2(B)$ and a TS ratio $>4(C)$. (D) SUP4 ${ }_{o c}$ variants identified as TS in met $22 \Delta$ have decreased tRNA levels at $37^{\circ} \mathrm{C}$ compared to $28^{\circ} \mathrm{C}$. Poison primer extension was used to quantify tRNA levels from the bulk RNA of cells grown in steady state at $28^{\circ} \mathrm{C}$ or $37^{\circ} \mathrm{C}$.

rose to $94.2 \%(277 / 294)$ for met22 $\Delta$ variants that were strongly TS (Fig. 4C).

Examination of several of the variants that were TS in a met $22 \Delta$ strain showed that the TS was frequently, but not always, associated with loss of tRNA. For several variants we observed substantially reduced tRNA levels in a met $22 \Delta$ strain grown at $37^{\circ} \mathrm{C}$, relative to $28^{\circ} \mathrm{C}$, including $\mathrm{G}_{68} \mathrm{C}, \mathrm{A}_{71} \mathrm{U}, \mathrm{C}_{66} \mathrm{~A}$, $\mathrm{U}_{2} \mathrm{C}$, and $\mathrm{C}_{5} \mathrm{U}$ (Fig. 4D; Supplemental Fig. S7A,B). For these tRNA variants, as well as for the $\mathrm{U}_{41} \mathrm{C} \mathrm{C}_{59} \mathrm{~A}$ double variant, decay occurred within $3 \mathrm{~h}$ (Supplemental Fig. S7C); in contrast, for some variants that were TS in a met22 $\Delta$ strain, such as the $\mathrm{A}_{38} \mathrm{U} \mathrm{U}_{39} \mathrm{C}$ and the $\mathrm{A}_{38} \mathrm{U} \mathrm{G}_{45} \mathrm{~A}$ variants, there was no observed decay in this timeframe.

Three lines of evidence suggest that the decay of met $22 \Delta \mathrm{TS}$ variants does not involve the nuclear surveillance pathway, which targets pre-tRNA and is the only other known pathway responsible for tRNA decay (Kadaba et al. 2004, 2006; Gudipati et al. 2012). First, flow cytometry analysis of $\mathrm{U}_{42} \mathrm{G}, \mathrm{G}_{68} \mathrm{C}$, and $\mathrm{G}_{7} \mathrm{U}$ variants demonstrated that the met $22 \Delta$ TS GFP $^{\text {FLOW }}$ phenotype was not suppressed by deletion of TRF4 (Fig. 5A), a known component of the nuclear surveillance pathway (Kadaba et al. 2004). Second, decay of the $\mathrm{G}_{68} \mathrm{C}$ variant occurred at the same rate with or without the transcription inhibitor thiolutin (Fig. 5B), suggesting that decay occurs at the level of mature tRNA. Third, decay of the $\mathrm{G}_{68} \mathrm{C}$ variant, as measured by tRNA levels, was not sup- pressed by deletion of either TRF4 or RRP6 (Fig. 5C), another component of the nuclear surveillance pathway (Kadaba et al. 2004).

Since the decay of met22 $\Delta$ TS variants did not appear to be due to the nuclear surveillance pathway, we considered the possibility that the RTD pathway could still function in a met $22 \Delta$ strain, although previous results had suggested otherwise (Chernyakov et al. 2008; Dewe et al. 2012). For example, a trm $8 \Delta$ trm $4 \Delta$ mutant is temperature sensitive because the RTD pathway degrades $\mathrm{tRNA}^{\mathrm{Val}(\mathrm{AAC})}$ due to the lack of $\mathrm{m}^{7} \mathrm{G}_{46}$ and $\mathrm{m}^{5} \mathrm{C}_{49}$, and this phenotype is fully suppressed by a met22 $\Delta$ mutation (Chernyakov et al. 2008). To examine whether RTD could act in a met $22 \Delta$ strain, we transformed a $\operatorname{trm} 8 \Delta \operatorname{trm} 4 \Delta$ met $22 \Delta$ strain with a plasmid overexpressing the $5^{\prime}-3^{\prime}$ exonuclease Rat1 under galactose control. Consistent with the ability of RTD to act in a met22 $2 \Delta$ mutant, overexpression of Rat1 and its partner Rail in media containing galactose caused temperature sensitivity in a trm $8 \Delta \operatorname{trm} 4 \Delta$ met $22 \Delta$ strain, whereas no difference was observed in media containing glucose, or with a vector control (Fig. 6). Similarly, the temperature sensitivity of a $\tan 1 \Delta$ trm44 $\Delta$ strain caused by decay of tRNA ${ }^{\text {Ser(CGA) }}$ lacking $\mathrm{ac}^{4} \mathrm{C}_{12}$ and $\mathrm{Um}_{44}$ by the RTD pathway is prevented by a met $22 \Delta$ mutation, and overexpression of Ratl and Rail caused mild temperature sensitivity in a $\tan 1 \Delta \operatorname{trm} 44 \Delta$ met $22 \Delta$ strain (Fig. 6). The same increased temperature sensitivity was observed when Xrn1, the other $5^{\prime}-3^{\prime}$ exonuclease of the RTD pathway, was overexpressed in these same strains (Fig. 6). These results argue that met $22 \Delta$ suppression of RTD is not absolute, and can be overcome under certain conditions.

\section{Temperature sensitivity results from a disruption of tRNA structure}

Given the high frequency of temperature sensitivity of stem variants in both WT and met $22 \Delta$ strains, we modeled the importance of thermodynamic features of secondary structure in the prediction of temperature sensitivity using a random forest model (Breiman 2001). The input features included $\Delta \Delta G^{\circ}$ and the ensemble defect (Zadeh et al. 2011) for each of the single and double variants at $22^{\circ} \mathrm{C}, 28^{\circ} \mathrm{C}, 37^{\circ} \mathrm{C}$, and $45^{\circ} \mathrm{C}$, as well as the location of the mutation within the molecule. The model was tested using a variation of leaveone-out cross validation that excluded from the training set all variants that shared any mutation with the variant to be tested (see Materials and Methods). Additionally, we 
A

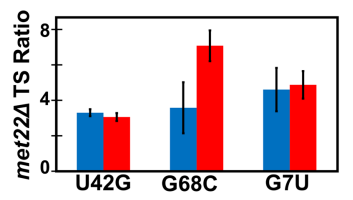

C

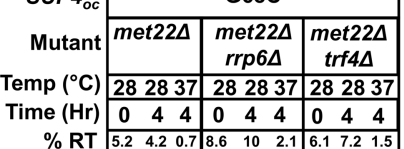

\begin{tabular}{lllllllllll} 
\% RT & 0 & 4 & 4 & 0 & 4 & 4 & 0 & 4 & 4 \\
\cline { 2 - 6 } & & 4.2 & 0.7 & 8.6 & 10 & 2.1 & 6.1 & 7.2 & 1.5 \\
\hline
\end{tabular}

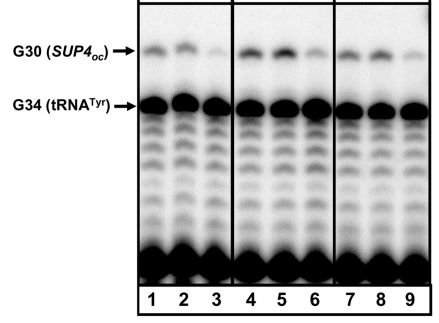

FIGURE 5. The nuclear surveillance pathway is likely not responsible for temperature dependent tRNA decay of tested variants in met22 $\Delta$ mutants. (A) Deletion of TRF4 in a met22 $\Delta$ strain does not decrease the TS ratio measured by $\mathrm{GFP}^{\mathrm{FLOW}}$ for three variants analyzed. $\mathrm{GFP}^{\mathrm{FLOW}}{ }_{28} /$ $\mathrm{GFP}^{\mathrm{FLOW}}{ }_{37}$ for met22 $2 \Delta$, blue, and $\operatorname{tr} 44 \Delta$ met $22 \Delta$, red. $(B)$ The $S U P 4_{o c} \mathrm{G} 68 \mathrm{C}$ variant is similarly degraded in a met $22 \Delta$ strain after shift to $37^{\circ} \mathrm{C}$ in the presence or absence of thiolutin. met $22 \Delta \mathrm{mu}$ tants bearing $S U P 4_{o c} G 68 \mathrm{C}$ and WT variants as indicated were treated with thiolutin or buffer, shifted to $37^{\circ} \mathrm{C}$ for indicated times, and levels of $S U P 4_{o c}$ and WT tRNA ${ }^{\mathrm{Tyr}}$ were analyzed from bulk RNA of harvested cells by poison primer extension. (C) The SUP4 ${ }_{o c} \mathrm{G} 68 \mathrm{C}$ variant is degraded at $37^{\circ} \mathrm{C}$ in a met $22 \Delta$ strain and in $\operatorname{trf} 4 \Delta$ and $r r p 6 \Delta$ derivatives. SUP4 ${ }_{o c}$ G68C tRNA levels were measured in a met $22 \Delta$, met $22 \Delta \operatorname{trf} 4 \Delta$, and a met $22 \Delta \operatorname{rrp} 6 \Delta$ strain $4 \mathrm{~h}$ after shift to $37^{\circ} \mathrm{C}$, as described in $B$.

tested a simple model that used only $\Delta \Delta G^{\circ}$ as input, analogous to the model previously used to predict RTD (Guy et al. 2014).

Both the random forest and simple $\Delta \Delta G^{\circ}$ models predicted temperature sensitivity with good accuracy. The receiver-operator curve of the temperature sensitivity prediction in WT cells using the random forest model had an area under the curve (AUC) of 0.73 (Fig. 7A, blue line), and comparable performance on met22 $\Delta$ cells, with AUC of 0.71 (Fig. $7 \mathrm{~B}$, blue line). The simple $\Delta \Delta G^{\circ}$ model performed slightly poorer than the random forest model, with an AUC of 0.70 (Fig. 7A, green line) for temperature sensitivity in WT cells and an AUC 0.68 (Fig. $7 \mathrm{~B}$, green line) in met22 cells. The performance of these predictions suggests that thermodynamic features are strongly predictive of the temperature sensitivity of $S U P 4_{o c}$ variants, and that the random forest model can better discriminate between TS and non-TS.

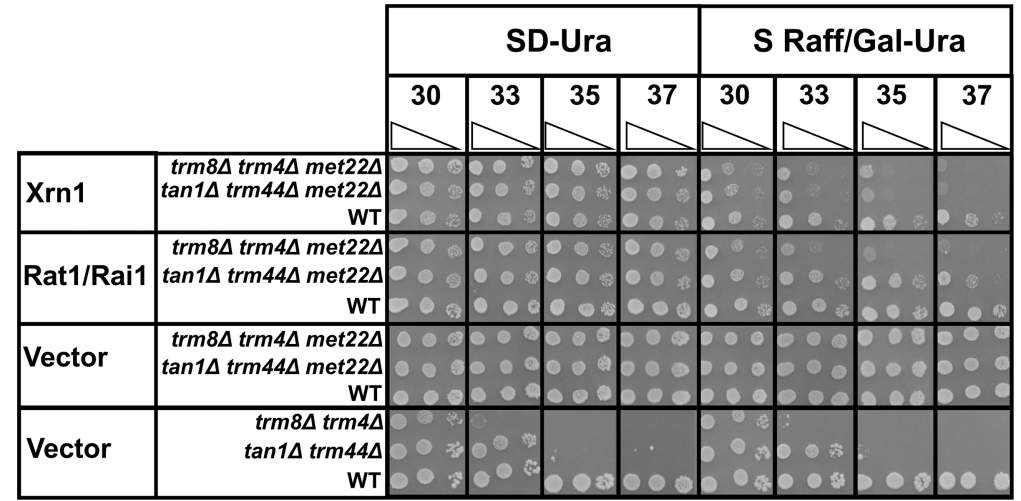

FIGURE 6. $5^{\prime}-3^{\prime}$ Exonucleases of the RTD pathway can function in a met $22 \Delta$ strain. trm $8 \Delta$ $\operatorname{trm} 4 \Delta$, and $\tan 1 \Delta \operatorname{trm} 44 \Delta$ mutants and their met $22 \Delta$ derivative strains (and a WT control) were transformed with plasmids expressing RAT1/RAI1 or XRN1 under control of the galactose promoter (or a vector control), and growth was analyzed in media containing galactose or glucose at the indicated temperatures. 

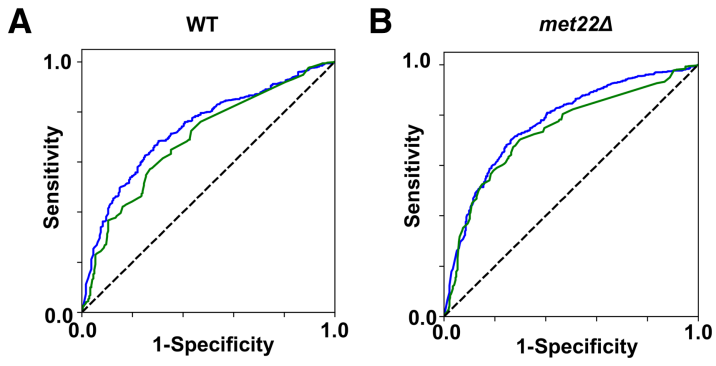

FIGURE 7. Temperature sensitivity can be predicted from thermodynamic properties of the tRNA sequence. $(A)$ Receiver-operator curve for prediction of temperature sensitivity in WT cells, using multiple features and a random forest model (blue), or a simple model using only $\Delta \Delta G^{\circ}$ (green). (B) Receiver-operator curve for prediction of temperature sensitivity in met22 $\Delta$ cells, as in $A$.

epistasis at either $28^{\circ} \mathrm{C}$ or $37^{\circ} \mathrm{C}$ had a $\mathrm{C}_{59}$ mutation, most frequently $\mathrm{C}_{59} \mathrm{~A}(17 / 67)$.

We found similar trends from analysis of positive epistasis of the 5069 double variants in a met22 $\Delta$ background with scores at both $28^{\circ} \mathrm{C}$ and $37^{\circ} \mathrm{C}$. Consistent with the strong suppression of RTD by a met $22 \Delta$ mutation (Chernyakov et al. 2008; Whipple et al. 2011), we identified more positive epistatic interactions in this background; 133 at $37^{\circ} \mathrm{C}$ and 85 at $28^{\circ} \mathrm{C}$ (Supplemental Fig. S8B), compared to 49 and 39, respectively, in WT. As observed in WT cells, positive epistasis in met $22 \Delta$ cells most frequently included the $\mathrm{C}_{59} \mathrm{~A}$ and $\mathrm{A}_{44} \mathrm{U}$ mutations, as well as base pair restoration mutations. In addition the positive epistasis data sets in met22 $\Delta$ cells included the $\mathrm{U}_{4} \mathrm{C}$ mutation, which is a known node of positive epistasis in WT cells because this mutation stabilizes the $\mathrm{U}_{4}-\mathrm{G}_{69}$ pair (Guy et al. 2014), but was not included here in WT cells because of our more stringent sequencing cutoffs. At $37^{\circ} \mathrm{C}$ in a met22 $\Delta$ strain there were 89 double variants with positive epistasis unique to $37^{\circ} \mathrm{C}$, including $34 / 89$ with a $\mathrm{U}_{4} \mathrm{C}$ mutation, 10 with a $\mathrm{C}_{59} \mathrm{~A}$ mutation, and 19 with an $\mathrm{A}_{44} \mathrm{U}$ mutation.

Further analysis of the variants with positive epistasis suggested that mutation of $\mathrm{C}_{59}$ improves some aspect of tertiary structure, since an overwhelming fraction of the other double variants with positive epistasis affected known or likely structural elements. For example, of the 21 double variants with positive epistasis in WT cells at both temperatures, the 13 variants lacking a $\mathrm{C}_{59}$ mutation included seven that restore base pairs, three with a mutation that restores or modifies a tertiary pair $\left(\mathrm{U}_{17} \mathrm{G} \mathrm{G}_{19} \mathrm{U}, \mathrm{A}_{29} \mathrm{U} \mathrm{A}_{44} \mathrm{U}\right.$, and $\mathrm{A}_{28} \mathrm{U} \mathrm{A}_{44} \mathrm{U}$ ) (Guy et al. 2014), two that affect the 13-22 pair found in many other tRNAs $\left(A_{13} U A_{22} G\right.$ and $\left.A_{13} U A_{22} U\right)$, and one that affects two residues involved in tertiary interactions $\left(\mathrm{A}_{9} \mathrm{G} \mathrm{G}_{45} \mathrm{C}\right)$ (Supplemental Table S3). Indeed, all but five of the 67 double variants with positive epistasis at either temperature had mutations in $\mathrm{C}_{59}$ or in residues involved in structure. Moreover, this trend continued in the positive epistasis data set in the met $22 \Delta$ strain. Of the 173 variants with positive epistasis at $28^{\circ} \mathrm{C}$ or $37^{\circ} \mathrm{C}, 24(13.9 \%)$ had the $\mathrm{C}_{59} \mathrm{~A}$ mutation $\left(\mathrm{C}_{59} \mathrm{G}\right.$ and $\mathrm{C}_{59} \mathrm{U}$ mutations did not pass quality control for this library). The other 149 variants included 23 that restored a base pair, 43 with a stabilizing $\mathrm{U}_{4} \mathrm{C}$ mutation, 24 with an $\mathrm{A}_{44} \mathrm{U}$ mutation likely stabilizing the $26-44$ tertiary pair, 40 affecting a tertiary interaction found in tRNAs and 19 variants with unexplained effects. Based on the very strong association in the positive epistasis data set of $\mathrm{C}_{59}$-containing double variants with variants containing known or likely structural mutations, we speculate that $\mathrm{C}_{59}$ mutations have a stabilizing effect on structure.

We ruled out the possibility that mutations of $\mathrm{C}_{59}$ increase transcription of $S U P 4_{o c}$ tRNA. The internal Pol III promoter of tRNA genes includes Box A nucleotides 8-21 and Box B nucleotides 53-61, with no defined role for $\mathrm{N}_{59}$ (Allison et al. 1983; Geiduschek and Tocchini-Valentini 1988; Marck et al. 2006). Consistent with the lack of a transcription role, we found that a $\mathrm{C}_{59} \mathrm{~A}$ mutation did not significantly increase $S U P 4_{o c}$ tRNA levels at either temperature, but dramatically increased tRNA levels of a de-stabilized $\mathrm{G}_{50} \mathrm{~A}$ variant at both temperatures, which is in accord with the positive epistasis score of $\mathrm{G}_{50} \mathrm{~A} \mathrm{C}_{59} \mathrm{~A}$ at both $28^{\circ} \mathrm{C}$ and $37^{\circ} \mathrm{C}$ in WT (Supplemental Fig. S9). Thus, the most parsimonious explanation is that the $\mathrm{C}_{59} \mathrm{~A}$ mutation confers stability to $S U P 4_{o c}$ tRNA rather than causing an increase in transcription.

\section{DISCUSSION}

One conclusion that arises from this work is the prevalence of temperature sensitivity among RNNA $^{\text {Tyr }}$ variants in the context of $S U P 4_{o c}$ suppression in WT cells. tRNAs are known to be stable, with half-lives in yeast on the order of $9 \mathrm{~h}$ (Gudipati et al. 2012), and half-lives in metazoans and protozoans on the order of days (Nwagwu and Nana 1980; Kanerva and Mäenpää 1981; Karnahl and Wasternack 1992). Moreover, tRNAs have a high tolerance for mutations, maintaining some function in a number of different single and double variants (Guy et al. 2014). However, our finding that $73.1 \%(656 / 897)$ of scoreable single and double variants were temperature sensitive emphasizes the extreme degree to which tRNA function is reduced by an increase of only $9^{\circ} \mathrm{C}$, from $28^{\circ} \mathrm{C}$ to $37^{\circ} \mathrm{C}$.

There are two notable exceptions to the prevalence of temperature sensitivity among variants. First, mutation of uridine residues in the D-loop that are normally modified to dihydrouridine were relatively benign. Since dihydrouridine is prevalent in psychrophiles and leads to increased conformational flexibility (Dalluge et al. 1996, 1997), it is possible that at high temperature the dihydrouridine contribution to tRNA flexibility is less important and that mutation of these residues is, therefore, benign. Second, the $\mathrm{A}_{46} \mathrm{G}$ mutation is associated with cold sensitivity as a single variant or in the context of several double variants. One interpretation of this result is that $\mathrm{A}_{46} \mathrm{G}$ leads to an inhibitory structure at lower temperature that is disrupted at higher temperature. Since $\mathrm{G}_{46}$ of tRNA ${ }^{\text {Phe }}$ is involved in a stabilizing base triple with $\mathrm{G}_{22}$ 
of the $\mathrm{C}_{13}-\mathrm{G}_{22}$ pair (Kim et al. 1974b), it is possible that the $\mathrm{G}_{46}$ variant of $S U P 4_{o c}$ forms an inhibitory triple with $\mathrm{G}_{23}$ of the $C_{12}-G_{23}$ pair, which is otherwise expected to pair with $A_{9}$.

Another conclusion is that a large fraction of the temperature sensitivity of SUP4 $4_{o c}$ variants in WT $\left(M E T 22^{+}\right)$cells can be attributed to RTD. Indeed $55.5 \%$ of variants with a TS ratio $\geq 2$ were RTD substrates at $28^{\circ} \mathrm{C}$ or $37^{\circ} \mathrm{C}$, and this value rose to $84 \%, 91.0 \%$, and $96.5 \%$ for TS ratios $\geq 3, \geq 4$, and $\geq 6$, respectively. This high degree of association of temperature sensitivity with RTD emphasizes that the RTD pathway is responsible for the majority of the temperaturedependent quality control for this tRNA species. In support of this claim, two TS variants of $S U P 4_{o c}$ that were RTD substrates had reduced tRNA at $37^{\circ} \mathrm{C}$ compared to $28^{\circ} \mathrm{C}$, which was partially rescued by a met $22 \Delta$ mutation, directly implicating the RTD pathway in the temperature sensitivity. Since the $5^{\prime}-3^{\prime}$ exonucleases of the RTD pathway are conserved in eukaryotes (Nagarajan et al. 2013), and there is evidence for RTD in humans at high temperature (Watanabe et al. 2013), we speculate that the RTD pathway might also have a role in temperature dependent quality control throughout eukaryotes.

The association of RTD with temperature sensitivity might also be extended to met $22 \Delta$ mutants, since an overwhelming majority of met $22 \Delta$ TS variants $(81.1 \%)$ were also substrates for RTD at $28^{\circ} \mathrm{C}$ or $37^{\circ} \mathrm{C}$. This temperature sensitivity in met22 $2 \Delta$ mutants could be due to RTD, because decay is occurring in most of the tested variants, and because the nuclear surveillance pathway does not contribute to this decay in several tested variants. Furthermore, both Rat1 and Xrn1 can act in met22 $2 \Delta$ mutants when overexpressed, implying that the exonucleases are not fully inhibited by this mutation; this conclusion is consistent with the observations that RAT1 is an essential gene (Amberg et al. 1992) and $x r n 1 \Delta$ mutants grow poorly (Kim et al. 1990), whereas a met $22 \Delta$ mutant is healthy (Chernyakov et al. 2008). However, it is also possible that decay occurs in these $S U P 4_{o c}$ variants in a met $22 \Delta$ strain due to another as yet unidentified pathway.

Our ability to predict temperature sensitivity of $S U P 4_{o c}$ variants in a WT strain by calculation of $\Delta G^{\circ}$ may be a consequence of the tight connection between temperature sensitivity and RTD, and between RTD and instability leading to exposure of the $5^{\prime}$ end (Whipple et al. 2011; Guy et al. 2014). However, we note that it is difficult to determine if the important free energy parameter for prediction of temperature sensitivity is $\Delta \Delta G^{\circ}$ (the difference in $\Delta G^{\circ}$ between the variant and the WT variant) or $\Delta G^{\circ}$ (the calculated free energy change of folding for each variant). Since the two parameters differ only by the constant represented by $\Delta G^{\circ}$ of the WT variant, their relative importance cannot be distinguished computationally. $\Delta \Delta G^{\circ}$ may be the more important factor since predicted $\Delta G^{\circ}$ values of tRNAs naturally exhibit a range of more than $10 \mathrm{kcal} / \mathrm{mol}$ within the same organism (Fig. 8; Chan and Lowe 2009). However, it is possible that variabilities in the contributions of modifications and specific

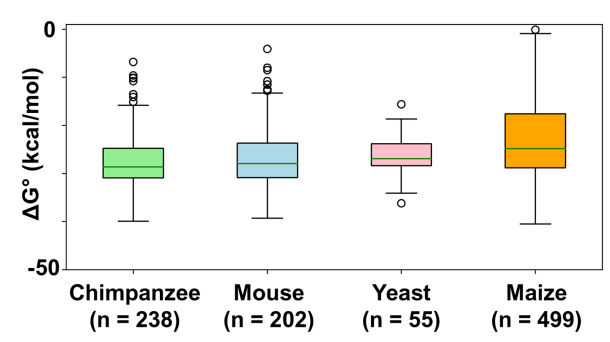

FIGURE 8. Distribution of predicted folding free energies for tRNA sequences from diverse species. Structure alignments were downloaded from the genomic tRNA database (Chan and Lowe 2009) and their energies were calculated using RNAstructure 5.8. Shown are all cytoplasmic tRNA sequences from chimpanzee (Pan troglodytes), mouse (Mus musculus), budding yeast (S. cerevisiae), and maize (Zea mays).

tertiary interactions in different tRNA species would buffer calculated $\Delta G^{\circ}$ values.

One such tertiary interaction that could vary in different tRNAs could involve $\mathrm{N}_{59}$. $\mathrm{N}_{59}$ of $S U P 4_{o c}$ may play a previously unappreciated role in $\mathrm{tRNA}^{\mathrm{Tyr}}$ structure, since 28 of 67 variants with positive epistasis in WT cells at either temperature had $\mathrm{C}_{59}$ mutations $\left(17 \mathrm{C}_{59} \mathrm{~A}, 9 \mathrm{C}_{59} \mathrm{G}\right.$, and $2 \mathrm{C}_{59} \mathrm{U}$ ), and all but five of the remainder were mutated in known secondary interactions or tertiary interactions documented in different tRNAs. The positive epistasis of variants with $\mathrm{C}_{59}$ mutations is general since it affected variants with mutations in every region of the tRNA. This positive epistasis of variants with $\mathrm{C}_{59}$ mutations was also prevalent in variants scored in a met $22 \Delta$ strain. Furthermore, although the B Box of the internal pol III promoter covers the region of nucleotides 53-61, nucleotide 59 has not been implicated as a promoter recognition element either by phylogenetic analysis (Marck et al. 2006) or by experiment (Geiduschek and TocchiniValentini 1988), consistent with our primer extension analysis. One interpretation of our results is that $\mathrm{C}_{59}$ destabilizes $S_{S P} 4_{o c}$ structure. $\mathrm{N}_{59}$ and $\mathrm{N}_{60}$ are known to stack on the Levitt base pair, the conserved $\mathrm{N}_{15}-\mathrm{N}_{48}$ tertiary base pair found in all tRNAs (Ladner et al. 1975; Giegé et al. 2012), but there are differences in the angle of the stacking in different tRNAs, which could change stability with different $\mathrm{N}_{59}$ residues.

The preponderance of temperature sensitivity among SUP ${ }_{o c}$ variants revealed in response to a $9^{\circ} \mathrm{C}$ temperature increase was unexpected. Previous physical analysis of tRNAs showed first melting transitions for unfolding of tertiary and secondary structures at or above $50^{\circ} \mathrm{C}$, albeit in buffers that differ from the cellular environment (Coutts et al. 1974; Crothers et al. 1974; Hilbers et al. 1976). Indeed, variants in our library with a $\Delta \Delta G^{\circ}$ as modest as $\sim 2.0 \mathrm{kcal} / \mathrm{mol}$ could result in greater than or equal to twofold loss of function at temperatures as low as $37^{\circ} \mathrm{C}$. We interpret these data to mean that the RTD pathway examines tRNAs to detect small changes in structure rather than folding transitions. In support of this interpretation, we previously showed that small differences in predicted stability of tRNA ${ }^{\text {Ser(CGA) }}$ 
variants could also provoke decay in vivo at elevated temperatures, increasing the exposure of the tRNA $5^{\prime}$ end to Rat1 and Xrn1 exonucleases (Whipple et al. 2011), which presumably allows the exonucleases to gain a foothold (Jinek et al. 2011). Subsequent analysis will be needed to address the mechanism by which small predicted stability changes can provoke drastic changes in stability in vivo.

\section{MATERIALS AND METHODS}

\section{Yeast strains}

The yeast strains used for $S U P 4_{o c}$ library construction, FACS, and analytical flow cytometry (YK 380-1: BY4741 can1::P $P_{G A L 1}-G F P_{o c^{-}}$ $P_{G A L 10}$-RFP and its met22 $\because: K a n R$ derivative YK 391-1) were as previously described (Guy et al. 2014). Individual $S U P 4_{o c}$ variants in plasmid AB230-1 were introduced into strains YK 380-1 and YK 391-1 by digestion with the restriction enzyme Stul (NEB), linear transformation at the ADE2 locus, and selection on S-His dropout medium. Three biological isolates were picked and saved at $-80^{\circ} \mathrm{C}$ in YPD $+8 \%$ DMSO.

\section{Plasmids}

Individual SUP4 ${ }_{o c}$ variants were constructed by ligation of overlapping oligomers (IDT) into the tRNA gene cassette of plasmid AB230-1 after digestion with $\mathrm{Bgl}$ II and XhoI to insert the tRNAs into the corresponding flanking regions of the $\mathrm{tH}(\mathrm{GUG}) \mathrm{G} 2$ gene, as previously described (Guy et al. 2014).

The final inserted sequence for $S U P 4_{o c}$ was as follows: $5^{\prime}$ agatctaacaaagttcataaagaaattaCTCTCGGTAGCCAAGTTGGTTTAA GGCGCAAGACTTTAATTTATCACTACGAAATCTTGAGATCGG GCGTTCGACTCGCCCCCGGGAGAttttttcctcgag-3' where the $S U P 4_{o c}$ exon sequence is capped and underlined, the anticodon is in bold, the intron is in italics, and the $5^{\prime}$ leader and the $3^{\prime}$ trailer derived from the $\mathrm{tH}(\mathrm{GUG}) \mathrm{G} 2$ flanking region is in lower case, with the flanking Bgl II and Xho I sequences underlined (Whipple et al. 2011). Variants constructed from SUP4 $4_{o c}$ all contained one or more mutations in the exon region.

\section{Analytical flow cytometry}

Strains were grown overnight at $28^{\circ} \mathrm{C}$ in $\mathrm{YP}$ medium containing $2 \%$ raffinose and $2 \%$ galactose supplemented with $80 \mathrm{mg} / \mathrm{L}$ adenine (YP Raff/Gal + Ade) for $\sim 12 \mathrm{~h}$ and then used to inoculate fresh prewarmed YP Raff/Gal + Ade at $28^{\circ} \mathrm{C}$ and $37^{\circ} \mathrm{C}$ for another $\sim 12 \mathrm{~h}$ of growth. Cells were diluted during growth as needed so that they were maintained in log phase, and were analyzed at an $\mathrm{OD}_{600}$ between 0.8 and 1.2. Samples were then analyzed by flow cytometry as previously described (Guy et al. 2014). The GFP ${ }^{\text {FLOW }}$ score for analyzed variants was derived from the median GFP divided by the median RFP for 10,000 recorded events with an RFP fluorescence above the cutoff of $5 \times 10^{3}$; standard deviations were derived from the analysis of biological triplicates in this manner and variants were normalized to the GFP ${ }^{\text {FLOW }}$ score of $S U P 4_{o c}$ measured in their respective conditions of analysis.

\section{SUP4 ${ }_{o c}$ library construction and analysis}

The libraries of yeast SUP4 ${ }_{o c}$ variants in WT (YK380-1) and met22 $\Delta$ (YK391-1) strains were constructed previously, and contained 3\% random mutations in $S U P 4_{o c}$ residues 1-33 and 38-73 (Guy et al. 2014). Each library was comprised of $\sim 200,000 S U P 4_{o c}$ variants that were transformed, derived from a master library of 325,000 E. coli plasmids. To analyze the yeast libraries, $\sim 4.5$ million cells of the yeast $S U P 4_{o c}$ libraries were grown in YP medium containing $2 \%$ raffinose supplemented with $80 \mathrm{mg} / \mathrm{L}$ adenine for $24 \mathrm{~h}$ at $28^{\circ} \mathrm{C}$ and then diluted to an $\mathrm{OD}_{600}$ of 0.05 into YP Raff/Gal + Ade at $37^{\circ} \mathrm{C}$. Cells were sorted by FACS on an Aria-11 cell sorter (BD Biosciences) at the University of Rochester Medical Center Flow Cytometry Core facility. The cells were sorted as previously described (Guy et al. 2014) into four bins based on GFP fluorescence whose borders were based on three control strains grown at $28^{\circ} \mathrm{C}$ with reproducible fluorescence intensities termed "GO" (RNA-ID Reporter without a $5^{\prime}$ stop codon in GFP), "STOP” (RNA-ID Reporter with a $5^{\prime}$ stop codon in GFP and no suppressing tRNA), and "CGA " (RNA-ID Reporter with the inhibitory codons CGA at the $5^{\prime}$ end of GFP); we also only collected cells with a minimum RFP fluorescence $>5 \times 10^{3}$ (Dean and Grayhack 2012; Guy et al. 2014). In total, at least 2 million cells were collected for each library and then plated onto YPD medium for $3 \mathrm{~d}$ at $25^{\circ} \mathrm{C}$ before being scraped, pooled, and stored at $-80^{\circ} \mathrm{C}$. Genomic DNA was isolated from frozen aliquots of the stored cells for each bin and used for deep sequencing.

\section{Isolation of bulk RNA}

WT and met22 $\Delta$ strains with integrated SUP $4_{o c}$ variants were grown in YPD media at $28^{\circ} \mathrm{C}$ or $37^{\circ} \mathrm{C}$ and harvested at $\mathrm{OD} \sim 1$, or at defined time points after shift from $28^{\circ} \mathrm{C}$ to $37^{\circ} \mathrm{C}$, or after addition of thiolutin to $5 \mu \mathrm{g} / \mathrm{mL}$ and shift to $37^{\circ} \mathrm{C}$. Bulk low-molecular-weight RNA was extracted from $\sim 2$ OD-mL pellets by hot phenol extraction followed by ethanol precipitation and resuspension in $\mathrm{ddH}_{2} \mathrm{O}$ as previously described (Jackman et al. 2003).

\section{Primer extension analysis of SUP4 ${ }_{o c}$ variants}

Poison primer extension assays were carried out as previously described (Guy et al. 2014), using one of two $5^{\prime}$ end labeled primers (complementary to nucleotides 57-37 [P5] or 62-43 [P7] of $S U P 4_{o c}$ in the presence of ddCTP. Reaction products were resolved on a $15 \%$ polyacrylamide $7 \mathrm{M}$ urea gel, and then dried and exposed to a phosphorimager plate for analysis.

\section{Sequencing}

The SUP4 $4_{o c}$ gene with $275^{\prime}$ and $163^{\prime}$ nucleotides was amplified for 20 cycles $\left(10 \mathrm{sec}\right.$ at $98^{\circ} \mathrm{C}, 30 \mathrm{sec}$ at $52^{\circ} \mathrm{C}$, and $30 \mathrm{sec}$ at $72^{\circ} \mathrm{C}$ ) from $\sim 1$ to $3 \mu \mathrm{g}$ of genomic DNA as previously described (Guy et al. 2014).

\section{Sequence assembly and quality filtering}

Sequences were trimmed and demultiplexed using a custom script. Forward and reverse reads were combined using Enrich version 0.2. 
Reads with a phred score lower than 30 were removed from subsequent analysis.

\section{Calculation of GFP ${ }^{\mathrm{SEQ}}$}

$\mathrm{GFP}^{\mathrm{SEQ}}$ was calculated as previously described (Guy et al. 2014). The number of reads in each bin was tabulated using Enrich version 0.2. The read counts for each variant in each bin were converted to an estimated number of cell counts by multiplying the frequency of each read in the bin by the number of cells collected for that bin. Cell counts for each variant were converted to a GFP ${ }^{\mathrm{SEQ}}$ score by taking the average GFP/RFP for each bin, weighted by the estimated number of cells for that bin, and normalized to a GFP $\mathrm{FLOW}^{\mathrm{FL}}$ value measured for the WT sequence. That is,

$$
\begin{aligned}
\mathrm{GFP}^{\mathrm{SEQ}}= & \frac{1}{\mathrm{GFP}^{\mathrm{WT}}} \sum_{n=1}^{4}(\text { cell counts for bin } n) \\
& \times\left(\text { median } \frac{\mathrm{GFP}}{\mathrm{RFP}} \text { for bin } n\right) / 4
\end{aligned}
$$

\section{Data quality control}

Data for individual variants were filtered for quality as previously described (Guy et al. 2014). A variant was discarded if it had fewer than 100 reads or fewer than 30 estimated cell counts

As we previously observed, PCR chimerism can lead to spurious WT reads for some variants. This is visible as a bimodal distribution of cell counts in the four bins. Variants were discarded if the number of cell counts in bins 1 and 4 were within 10-fold of one another and bins 1 and 4 were the bins with the highest number of cell counts. A manual inspection of the double variants indicated this filtering scheme was sufficient to remove the variants with invalid scores.

An interactive graphic allowing visualization of function under each condition, RTD, TS, and epistasis is available at https://rna. urmc.rochester.edu/tRNA/2017-10-02_interactive_trna.html.

\section{Statistical significance of enrichment of TS variants in stems}

The statistical significance of the enrichment of TS variants in stem regions was assessed using a $\chi^{2}$ test, with a Type I error rate, $\alpha$, set to 0.05 .

\section{Thermodynamic calculations}

The RNAstructure software package version 5.8 (Reuter and Mathews 2010) was used for all thermodynamic calculations, using folding free energy changes adjusted to the appropriate temperature (Lu et al. 2006).

The $\Delta \Delta G^{\circ}$ value for each variant was calculated with the nearest neighbor rules, using the simplified non-logarithmic formation of the multibranch loop energy used by the structure prediction algorithms (efn2 flag -simple) (Mathews et al. 2004; Reuter and Mathews 2010). Because SUP4 $4_{o c}$ contains numerous G-U wobble pairs, we included a recently updated set of parameter values for G-U base pair stacks (Chen et al. 2012). Nucleotides in the reference structure were unpaired in the calculation if they were mutated in a way that prevented canonical A-U, G-C, or G-U base pairing.

The normalized ensemble defect for each variant is given by

$$
\begin{aligned}
\mathrm{NED}= & \frac{1}{n} \\
& \times\left(\sum_{i=1}^{n} \pi_{i} \times\left(1-P_{i}^{\text {paired }}\right)+\sum_{i=1}^{n}\left(1-\pi_{i}\right) \times\left(1-P_{i}^{\text {unpaired }}\right)\right),
\end{aligned}
$$

where $n$ is the length of the nucleotide sequence (in this case $78 \mathrm{nt}$ ), $P_{i}^{\text {unpaired }}$ is the estimated probability that the nucleotide at position $i$ is unpaired, $P_{i}^{\text {paired }}$ is the estimated probability the nucleotide at position $i$ is paired to its correct pairing partner in the reference structure, and $\pi_{\mathrm{i}}$ is an indicator variable taking a value of one if the nucleotide at position $i$ is paired in the reference structure and zero if it is unpaired in the reference structure (Zadeh et al. 2011). Thus, the normalized ensemble defect is the average probability that a nucleotide is not forming the desired secondary structure (either a specific pair or being unpaired).

\section{Prediction of temperature sensitivity}

Temperature sensitivity was predicted for each variant for which temperature sensitivity could be assessed using the RandomForestClassifier model from scikit-learn (Pedregosa et al. 2011 ) with input features of $\Delta \Delta G^{\circ}$ at $28^{\circ} \mathrm{C}, \Delta \Delta G^{\circ}$ at $37^{\circ} \mathrm{C}$, ED at $28^{\circ} \mathrm{C}$, and $\mathrm{ED}$ at $37^{\circ} \mathrm{C}$. Additional features tested included $\Delta \Delta G^{\circ}$ and $\mathrm{ED}$ at $22^{\circ} \mathrm{C}$ and $45^{\circ} \mathrm{C}$, and indicator variables indicating presence of a mutation in the acceptor stem, D-stem, anticodon stem, T-stem, a mismatch position adjacent to any stem, or in a loop not adjacent to a stem.

Cross validation was performed using the leave-one-out method. For each variant in the data set, the model was retrained on the set of variants that contained no mutations in common with the variant to be tested, and temperature sensitivity was predicted for the remaining variant.

The random forest classifier produces a value between zero and one that represents the model's confidence that this example belongs to the positive class (temperature sensitive variants, in this case). For the reported accuracy scores, a variant was considered "predicted TS" if the model predicted 50\% confidence that the variant was TS. Receiver-operator characteristic curves were generated by assessing sensitivity and false positive rate at every possible threshold of confidence values.

\section{SUPPLEMENTAL MATERIAL}

Supplemental material is available for this article.

\section{ACKNOWLEDGMENTS}

We thank Elizabeth Grayhack for valuable discussions during the course of this work and comments on the manuscript. This research was supported by National Institutes of Health (NIH) grant GM052347 to E.M.P., NIH grant R01 GM076485 to D.H.M., and NIH grant P41 GM103533 to S.F. S.F. is an investigator of the Howard Hughes Medical Institute.

Received October 24, 2017; accepted December 14, 2017. 


\section{REFERENCES}

Alexandrov A, Chernyakov I, Gu W, Hiley SL, Hughes TR, Grayhack EJ, Phizicky EM. 2006. Rapid tRNA decay can result from lack of nonessential modifications. Mol Cell 21: 87-96.

Allison DS, Goh SH, Hall BD. 1983. The promoter sequence of a yeast tRNA $^{\text {Tyr }}$ gene. Cell 34: 655-664.

Amberg DC, Goldstein AL, Cole CN. 1992. Isolation and characterization of RAT1: an essential gene of Saccharomyces cerevisiae required for the efficient nucleocytoplasmic trafficking of mRNA. Genes Dev 6: 1173-1189.

Breiman L. 2001. Random forests. Mach Learn 45: 5-32.

Chan PP, Lowe TM. 2009. GtRNAdb: a database of transfer RNA genes detected in genomic sequence. Nucleic Acids Res 37: D93-D97.

Chen JL, Dishler AL, Kennedy SD, Yildirim I, Liu B, Turner DH, Serra MJ. 2012. Testing the nearest neighbor model for canonical RNA base pairs: revision of GU parameters. Biochemistry 51: 3508-3522.

Chernyakov I, Whipple JM, Kotelawala L, Grayhack EJ, Phizicky EM. 2008. Degradation of several hypomodified mature tRNA species in Saccharomyces cerevisiae is mediated by Met22 and the $5^{\prime}-3^{\prime}$ exonucleases Rat1 and Xrn1. Genes Dev 22: 1369-1380.

Chowdhury S, Ragaz C, Kreuger E, Narberhaus F. 2003. Temperaturecontrolled structural alterations of an RNA thermometer. J Biol Chem 278: 47915-47921.

Cimdins A, Klinkert B, Aschke-Sonnenborn U, Kaiser FM, Kortmann J, Narberhaus F. 2014. Translational control of small heat shock genes in mesophilic and thermophilic cyanobacteria by RNA thermometers. RNA Biol 11: 594-608.

Cochella L, Green R. 2005. An active role for tRNA in decoding beyond codon:anticodon pairing. Science 308: 1178-1180.

Coutts SM, Gangloff J, Dirheimer G. 1974. Conformational transitions in tRNA ${ }^{\text {Asp }}$ (brewer's yeast). Thermodynamic, kinetic, and enzymic measurements on oligonucleotide fragments and the intact molecule. Biochemistry 13: 3938-3948.

Crothers DM, Cole PE, Hilbers CW, Shulman RG. 1974. The molecular mechanism of thermal unfolding of Escherichia coli formylmethionine transfer RNA. J Mol Biol 87: 63-88.

Dalluge JJ, Hamamoto T, Horikoshi K, Morita RY, Stetter KO, McCloskey JA. 1997. Posttranscriptional modification of tRNA in psychrophilic bacteria. J Bacteriol 179: 1918-1923.

Dalluge JJ, Hashizume T, Sopchik AE, McCloskey JA, Davis DR. 1996. Conformational flexibility in RNA: the role of dihydrouridine. Nucleic Acids Res 24: 1073-1079.

Dean KM, Grayhack EJ. 2012. RNA-ID, a highly sensitive and robust method to identify cis-regulatory sequences using superfolder GFP and a fluorescence-based assay. RNA 18: 2335-2344.

Demeshkina N, Jenner L, Yusupova G, Yusupov M. 2010. Interactions of the ribosome with mRNA and tRNA. Curr Opin Struct Biol 20: 325-332.

Dewe JM, Whipple JM, Chernyakov I, Jaramillo LN, Phizicky EM. 2012. The yeast rapid tRNA decay pathway competes with elongation factor 1A for substrate tRNAs and acts on tRNAs lacking one or more of several modifications. RNA 18: 1886-1896.

Fortner DM, Troy RG, Brow DA. 1994. A stem/loop in U6 RNA defines a conformational switch required for pre-mRNA splicing. Genes Dev 8: $221-233$.

Galtier N, Lobry JR. 1997. Relationships between genomic G+C content, RNA secondary structures, and optimal growth temperature in prokaryotes. J Mol Evol 44: 632-636.

Geiduschek EP, Tocchini-Valentini GP. 1988. Transcription by RNA polymerase III. Annu Rev Biochem 57: 873-914.

Giegé R, Jühling F, Pütz J, Stadler P, Sauter C, Florentz C. 2012. Structure of transfer RNAs: similarity and variability. WIREs RNA 3: $37-61$.

Giege R, Sissler M, Florentz C. 1998. Universal rules and idiosyncratic features in tRNA identity. Nucleic Acids Res 26: 5017-5035.

Grosjean H, Westhof E. 2016. An integrated, structure- and energybased view of the genetic code. Nucleic Acids Res 44: 8020-8040.
Gudipati RK, Xu Z, Lebreton A, Séraphin B, Steinmetz LM, Jacquier A, Libri D. 2012. Extensive degradation of RNA precursors by the exosome in wild-type cells. Mol Cell 48: 409-421.

Guy MP, Young DL, Payea MJ, Zhang X, Kon Y, Dean KM, Grayhack EJ, Mathews DH, Fields S, Phizicky EM. 2014. Identification of the determinants of tRNA function and susceptibility to rapid tRNA decay by high-throughput in vivo analysis. Genes Dev 28: 1721-1732.

Helm M, Giegé R, Florentz C. 1999. A Watson-Crick base-pair-disrupting methyl group (m1A9) is sufficient for cloverleaf folding of human mitochondrial tRNA ${ }^{\text {Lys }}$. Biochemistry 38: 13338-13346.

Hilbers CW, Robillard GT, Shulman RG, Blake RD, Webb PK, Fresco R, Riesner D. 1976. Thermal unfolding of yeast glycine transfer RNA. Biochemistry 15: 1874-1882.

Jackman JE, Montange RK, Malik HS, Phizicky EM. 2003. Identification of the yeast gene encoding the tRNA $\mathrm{m}^{1} \mathrm{G}$ methyltransferase responsible for modification at position 9. RNA 9: 574-585.

Jinek M, Coyle SM, Doudna JA. 2011. Coupled 5' nucleotide recognition and processivity in Xrn1-mediated mRNA decay. Mol Cell 41: 600-608.

Johansson MJ, Esberg A, Huang B, Bjork GR, Bystrom AS. 2008. Eukaryotic wobble uridine modifications promote a functionally redundant decoding system. Mol Cell Biol 28: 3301-3312.

Kadaba S, Krueger A, Trice T, Krecic AM, Hinnebusch AG, Anderson J. 2004. Nuclear surveillance and degradation of hypomodified initiator tRNA ${ }^{\mathrm{Met}}$ in S. cerevisiae. Genes Dev 18: 1227-1240.

Kadaba S, Wang X, Anderson JT. 2006. Nuclear RNA surveillance in Saccharomyces cerevisiae: Trf4p-dependent polyadenylation of nascent hypomethylated tRNA and an aberrant form of 5S rRNA. RNA 12: 508-521.

Kanerva PA, Mäenpää PH. 1981. Codon-specific serine transfer ribonucleic acid degradation in avian liver during vitellogenin induction. Acta Chem Scand B 35: 379-385.

Karnahl U, Wasternack C. 1992. Half-life of cytoplasmic rRNA and tRNA, of plastid rRNA and of uridine nucleotides in heterotrophically and photoorganotrophically grown cells of Euglena gracilis and its apoplastic mutant W3BUL. Int J Biochem 24: 493-497.

Kim J, Ljungdahl PO, Fink GR. 1990. kem mutations affect nuclear fusion in Saccharomyces cerevisiae. Genetics 126: 799-812.

Kim SH, Suddath FL, Quigley GJ, McPherson A, Sussman JL, Wang AH, Seeman NC, Rich A. 1974a. Three-dimensional tertiary structure of yeast phenylalanine transfer RNA. Science 185: 435-440.

Kim SH, Sussman JL, Suddath FL, Quigley GJ, McPherson A, Wang AH, Seeman NC, Rich A. 1974b. The general structure of transfer RNA molecules. Proc Natl Acad Sci 71: 4970-4974.

Kortmann J, Narberhaus F. 2012. Bacterial RNA thermometers: molecular zippers and switches. Nat Rev Microbiol 10: 255-265.

Kramer EB, Hopper AK. 2013. Retrograde transfer RNA nuclear import provides a new level of tRNA quality control in Saccharomyces cerevisiae. Proc Natl Acad Sci 110: 21042-21047.

Ladner JE, Jack A, Robertus JD, Brown RS, Rhodes D, Clark BF, Klug A. 1975. Structure of yeast phenylalanine transfer RNA at $2.5 \mathrm{~A}$ resolution. Proc Natl Acad Sci 72: 4414-4418.

Ledoux S, Olejniczak M, Uhlenbeck OC. 2009. A sequence element that tunes Escherichia coli tRNA ${ }_{\text {GGC }}$ to ensure accurate decoding. Nat Struct Mol Biol 16: 359-364.

Li C, Qian W, Maclean CJ, Zhang J. 2016. The fitness landscape of a tRNA gene. Science 352: 837-840.

Ling J, Reynolds N, Ibba M. 2009. Aminoacyl-tRNA synthesis and translational quality control. Annu Rev Microbiol 63: 61-78.

Lu ZJ, Turner DH, Mathews DH. 2006. A set of nearest neighbor parameters for predicting the enthalpy change of RNA secondary structure formation. Nucleic Acids Res 34: 4912-4924.

Maehigashi T, Dunkle JA, Miles SJ, Dunham CM. 2014. Structural insights into +1 frameshifting promoted by expanded or modification-deficient anticodon stem loops. Proc Natl Acad Sci 111: 12740-12745.

Marck C, Kachouri-Lafond R, Lafontaine I, Westhof E, Dujon B, Grosjean H. 2006. The RNA polymerase III-dependent family of genes in hemiascomycetes: comparative RNomics, decoding 


\section{Payea et al.}

strategies, transcription and evolutionary implications. Nucleic Acids Res 34: 1816-1835.

Mathews DH, Disney MD, Childs JL, Schroeder SJ, Zuker M, Turner DH. 2004. Incorporating chemical modification constraints into a dynamic programming algorithm for prediction of RNA secondary structure. Proc Natl Acad Sci 101: 7287-7292.

Nagarajan VK, Jones CI, Newbury SF, Green PJ. 2013. XRN 5' $\rightarrow 3^{\prime}$ exoribonucleases: structure, mechanisms and functions. Biochim Biophys Acta 1829: 590-603.

Nwagwu M, Nana M. 1980. Ribonucleic acid synthesis in embryonic chick muscle, rates of synthesis and half-lives of transfer and ribosomal RNA species. J Embryol Exp Morphol 56: 253-267.

Ohira T, Suzuki T. 2011. Retrograde nuclear import of tRNA precursors is required for modified base biogenesis in yeast. Proc Natl Acad Sci 108: $10502-10507$.

Pedregosa F, Varoquaux G, Gramfort A, Michel V, Thirion B, Grisel O, Blondel M, Prettenhofer P, Weiss R, Dubourg V, et al. 2011. Scikitlearn: machine learning in Python. J Mach Learn Res 12: 2825-2830.

Pitt JN, Ferre-D'Amare AR. 2010. Rapid construction of empirical RNA fitness landscapes. Science 330: 376-379.

Pütz J, Florentz C, Benseler F, Giegé R. 1994. A single methyl group prevents the mischarging of a tRNA. Nat Struct Biol 1: 580-582.

Reuter JS, Mathews DH. 2010. RNAstructure: software for RNA secondary structure prediction and analysis. BMC Bioinformatics 11: 129.

Rozov A, Demeshkina N, Khusainov I, Westhof E, Yusupov M, Yusupova G. 2016. Novel base-pairing interactions at the tRNA wobble position crucial for accurate reading of the genetic code. Nat Commun 7: 10457.

Ruiz-Pesini E, Lott MT, Procaccio V, Poole JC, Brandon MC, Mishmar D, Yi C, Kreuziger J, Baldi P, Wallace DC. 2007. An enhanced MITOMAP with a global mtDNA mutational phylogeny. Nucleic Acids Res 35: D823-D828.
Schmeing TM, Voorhees RM, Kelley AC, Gao YG, Murphy FV IV, Weir JR, Ramakrishnan V. 2009. The crystal structure of the ribosome bound to EF-Tu and aminoacyl-tRNA. Science 326: 688-694.

Shaheen HH, Hopper AK. 2005. Retrograde movement of tRNAs from the cytoplasm to the nucleus in Saccharomyces cerevisiae. Proc Natl Acad Sci 102: 11290-11295.

Shepotinovskaya I, Uhlenbeck OC. 2013. tRNA residues evolved to promote translational accuracy. RNA 19: 510-516.

Takano A, Endo T, Yoshihisa T. 2005. tRNA actively shuttles between the mucleus and cytosol in yeast. Science 309: 140-142.

Turner DH, Mathews DH. 2010. NNDB: the nearest neighbor parameter database for predicting stability of nucleic acid secondary structure. Nucleic Acids Res 38: D280-D282.

Valle M, Zavialov A, Li W, Stagg SM, Sengupta J, Nielsen RC, Nissen P, Harvey SC, Ehrenberg M, Frank J. 2003. Incorporation of aminoacyl-tRNA into the ribosome as seen by cryo-electron microscopy. Nat Struct Biol 10: 899-906.

Watanabe K, Miyagawa R, Tomikawa C, Mizuno R, Takahashi A, Hori H, Ijiri K. 2013. Degradation of initiator tRNA ${ }^{\text {Met }}$ by Xrn1/2 via its accumulation in the nucleus of heat-treated HeLa cells. Nucleic Acids Res 41: 4671-4685.

Westhof E, Dumas P, Moras D. 1985. Crystallographic refinement of yeast aspartic acid transfer RNA. J Mol Biol 184: 119-145.

Whipple JM, Lane EA, Chernyakov I, D’Silva S, Phizicky EM. 2011. The yeast rapid tRNA decay pathway primarily monitors the structural integrity of the acceptor and T-stems of mature tRNA. Genes Dev 25: 1173-1184.

Zadeh JN, Wolfe BR, Pierce NA. 2011. Nucleic acid sequence design via efficient ensemble defect optimization. J Comput Chem 32: 439-452.

Zhou J, Lancaster L, Donohue JP, Noller HF. 2013. Crystal structures of EF-G-ribosome complexes trapped in intermediate states of translocation. Science 340: 1236086. 

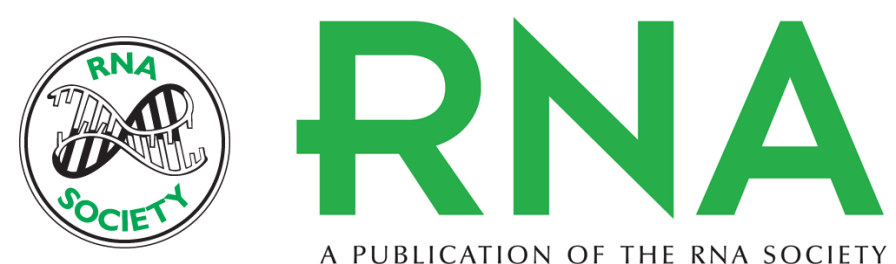

A PUBLICATION OF THE RNA SOCIETY

\section{Widespread temperature sensitivity and tRNA decay due to mutations in a yeast tRNA}

Matthew J. Payea, Michael F. Sloma, Yoshiko Kon, et al.

RNA 2018 24: 410-422 originally published online December 19, 2017

Access the most recent version at doi:10.1261/rna.064642.117

\section{Supplemental Material}

References

Creative Commons License

Email Alerting
Service
http://rnajournal.cshlp.org/content/suppl/2017/12/19/rna.064642.117.DC1

This article cites 67 articles, 29 of which can be accessed free at: http://rnajournal.cshlp.org/content/24/3/410.full.html\#ref-list-1

This article is distributed exclusively by the RNA Society for the first 12 months after the full-issue publication date (see http://rnajournal.cshlp.org/site/misc/terms.xhtml). After 12 months, it is available under a Creative Commons License (Attribution-NonCommercial 4.0 International), as described at http://creativecommons.org/licenses/by-nc/4.0/.

Receive free email alerts when new articles cite this article - sign up in the box at the top right corner of the article or click here.

To subscribe to $R N A$ go to:

http://rnajournal.cshlp.org/subscriptions 